\title{
Ultrastructure of royal palm (Roystonea regia) leaf sheath
}

\author{
ULFA ADZKIA ${ }^{1}$, NARESWORO NUGROHO ${ }^{1}$, ISKANDAR Z. SIREGAR ${ }^{2}$, LINA KARLINASARI ${ }^{1, \bullet}$ \\ ${ }^{1}$ Department of Forest Products, Faculty of Forestry, Institut Pertanian Bogor. Jl. Lingkar Akademik, Dramaga, Bogor 16680, West Java, Indonesia. \\ Tel./fax.:+62-251-862-6806, `email: karlinasari@apps.ipb.ac.id \\ ${ }^{2}$ Department of Silviculture, Faculty of Forestry, Institut Pertanian Bogor.Jl. Lingkar Akademik, Dramaga, Bogor 16680, West Java, Indonesia
}

Manuscript received: 4 December 2019. Revision accepted: 9 February 2020.

\begin{abstract}
Adzkia U, Nugroho N, Siregar IZ, Karlinasari L. 2020. Ultrastructure of royal palm (Roystonea regia) leaf sheath. Biodiversitas 21: 967-974. The royal palm (Roystonea regia (Kunth) F.Cook is one of the palm species that are many planted along the streets as part of urban landscapes. As biologically products, in nature they can self-cleaning with drop off their big leaves. The study aims to examine the morphological characteristics of ultrastructure and elemental content, crystallinity, as well as fibers derivation characteristics from the royal palm. The samples were taken out from leaf sheaths that divided into three sections along the width of i.e. outside, middle, and inside; in two conditions of leaf sheaths namely green and brownish-dry. The morphology structure and elemental content were observed by the Scanning Electron Microscopy (SEM) and the Energy Dispersive X-ray analysis (EDX), while the crystallinity was analyzed using X-ray diffraction (XRD), and fiber characteristics were measured to determine cell dimensions as well as to calculate Runkle ratio (RR), muhlsteph ratio (MR), coefficient of rigidity (CR), felting powder (FP), and flexibility ratio (FR). The diameter of palm fiber bundles was decreased from outside towards inside. The model of vascular tissue was rounded which located in the central region of the fiber bundles. The silicon content in the inside section was lower than those in the middle and outside sections. It was in line with the degree of crystallinity in the inside section which that higher than other sections. The highest degree of crystallinity was about $18 \%$. The fiber length of royal palm leaf sheath was in values around $6000 \mu$ m. However, the royal palm leaf sheath had thick fiber walls and thin lumen, as well as other fiber derivation characteristics of muhlsteph ratio, the coefficient of rigidity and the flexibility ratio, were in low-quality values. For that reason, the study provides information that the royal palm sheath was recommended as a composite reinforcing material.
\end{abstract}

Keywords: Crystallinity, fiber length, Roystonea regia, silica, vascular bundles

\section{INTRODUCTION}

Natural fibers are renewable resources that can be found from many raw materials such as wood, cotton, flax, kenaf, hemp, and others including from monocotyledons i.e. bamboo and palms plants. They are known as cheaper materials, low weight, low abrasive property, renewable and degradable which providing a solution to environmental pollution by finding a new composite product. As agricultural and plantation wastes, the abundance of natural fibers has potentially used for reinforcing materials. The development of natural fiber composite products in the market has been segmented not only for conventional composite products but also into inorganic compound, natural polymer, and synthetic polymer-based on matrix for automotive, construction, electronics, and sporting goods purposes (Khalil et al. 2012, Kumar et al. 2016, Chen et al. 2017, Chauhan and Bhushan 2017).

The palm plants mostly planted and distributed in tropical Asia and America region with some species in Africa which has about 184 genera and more than 2400 species (Pei et al. 1991; Dransfield et al. 2008; Zhai 2013). There are some palm has high-value and common as ornamental plants in many areas, especially in urban area such as Roystonea regia, Veitchia merillii (Christmas palm), Ptychosperm macarthurii (Macarthur palm), Palmiste gargoulette (Bottle palm), Livistona saribus
(Taraw palm), etc (Anonymous 2019). The royal palm (Roystonea regia (Kunth) F.Cook also known as Roystonea elata (W. Bartram) F. Harper) from family Arecaceae are many planted along the streets as part of urban landscapes. This species is originating from the American continent especially from south Florida and Cuba, including species quickly grows which can reach a height of more than 25 meters with a diameter of up to $45 \mathrm{~cm}$ (Broschat 2017). The bottom of the stem is brownish grey, and the top is bright green, green midrib canopy can reach a length of 1.5 $\mathrm{m}$ in diameter $20-30 \mathrm{~cm}$ (Figure 1) The royal palm leaves also have a slippery impression on their upper and lower surfaces. In general, the palm leaf consists of three distinct parts, the rachis bearing the leaflets, a long or short petiole, and the basal leaf-sheath. The leaf at its insertion always completely encircles the stem but above this, the sheath may be either open or closed (Zhai 2013). The royal palms are considered self-cleaning with naturally dying old leaves will cleanly drop off by themselves, at a rate of about one leaf per month. Sometimes the eliminates is needed through trimming off the old dead leaves which has the sheer size ( $3 \mathrm{~m}$ to $4.5 \mathrm{~m}$. long) and weight (up to $22.7 \mathrm{~kg}$ when fresh). The big size of these leaves can cause injury to people and damage to property when they fall (Broschat 2017). Several studies have been performed on the application of royal palm fiber for biocomposite (Bryan and Daniella 2012; Pohan et al. 2018). 
The morphological of the royal palm is interesting to be investigated. The knowledge of morphology is important for exploring the potential broad applications in the processing of royal palm as the raw material of a product. This paper presents the morphological characteristics of ultrastructure, crystallinity, and fibers derivation characteristics from the royal palm. The main objective of this study was to provide further information about the morphological of the royal palm in terms of the widespread utilization of natural fiber resources.

\section{MATERIALS AND METHODS}

\section{Materials}

The royal palm was used in this study were obtained from roadside plants in Darmaga campus area of IPB University (6³3'24.68" S 106º $43^{\prime} 47.56$ "E). The leaves waste was collected in green and brownish-dry color for every 10 samples of the leaf. The leaf sheath part of royal palm was taken out for this study and dividing into parts or sections along the width i.e. outside, middle and inside parts (Figure 2).

\section{Methods}

\section{Scanning Electron Microscopy (SEM) - Energy Dispersive} $X$-ray $(E D X)$

The morphology structure and elemental content were observed by the Scanning Electron Microscopy (SEM) and the Energy Dispersive X-ray analysis (EDX), respectively. The samples of leaf sheaths were prepared in a clean condition free from dust and other materials and have passed the process of stabilizing, rinsing, dehydrating, drying, mounting, and coating the specimen. The samples were in the dimension of length, width $(0.5 \mathrm{~cm} \times 0.5 \mathrm{~cm})$ and the thickness which was adjusted to the leaf sheath. All the samples were coated with gold. The coating was carried out with a thin layer from 20 to $30 \mathrm{~nm}$ which aims to increase the conductivity (Ayub et al. 2017). The observations were made with SEM-EDX (ZEISS EVO'50) at a voltage of $15 \mathrm{kV}$. Anatomical characteristics examined comprised the area of vascular bundles in transversal crosssection images including the types of fiber bundles. Software ImageJ ( $v$ 1.46) was used to calculate the dimension of vascular bundles.

\section{Silica content analysis}

Silica content determination was performed based on SNI 14-1031 (SNI 1989) using $5 \pm 0.01 \mathrm{~g}$ of 40-60 mesh leaf sheath powder which was heated in a furnace at $600{ }^{\circ} \mathrm{C}$ for 3 hours. After ash content obtained and proceeded in the chemical process, the silica content was calculated based on a percentage of the constant weight to powder dry weight.

\section{X-Ray Diffraction (XRD)}

The XRD was used to observe the degree of crystallinity of royal palm leaf sheath. The sample was prepared to informing of powder with the dimension from 40 to 60 mesh in 2 grams. The degree of crystallinity was analyzed using XRD-7000 (Shimadzu, Japan) with monochromatic CuKa radiation $(\lambda=0.15418 \mathrm{~nm})$. The observed was performed at a voltage of $40 \mathrm{kV}$, a current of $30 \mathrm{~mA}$ with a scanning angle range of $2 \Theta$ between 5 and $60^{\circ}$ and a scanning speed of $2^{\circ} / \mathrm{min}$. The crystallinity was calculated using Equation 1, where $I_{200}$ is the intensity when the maximum peak of types $I$ and $I_{a m}$ cellulose is the diffraction intensity of the amorphous portion (Wada and Okana 2001 and Gumuskaya et al. 2003).

$$
C=\frac{t_{2 a n}-I a m}{I_{2 n 0}} \times 100
$$

\section{Fiber measurements}

Fiber measurements were conducted based on the research Zhai et al. (2013). The royal palm leaf sheath was cut into the length, width, and thickness $(3 \mathrm{~cm} \times 2 \mathrm{~mm} \times 2$ $\mathrm{mm})$, and the samples were put in the tube reaction. The maceration process was carried out on in a mixture (50:50) of $60 \%$ aqueous acetic glacial acid and $30 \%$ aqueous hydrogen peroxide. The sample was heated into waterbath $\left(80^{\circ} \mathrm{C}\right)$ from 1 to 3 days until the sample in the white colors and the fibers was separates. The sample was stained with safranin. The length of fiber observation was used the plan lens with magnification 2 times, while the diameter of fiber used magnification 10 times. The observation was conducted to 75 fiber each part of the leaf sheath. The measurement of length fiber, width fiber, and lumen diameter was measured with Image J software (v.14.6). Following parameters of Runkle ratio (RR), muhlsteph ratio (MR), coefficient of rigidity (CR), felting powder (FP), and flexibility ratio (FR) were calculated as stated by Zhai et al. (2013), based on Equation 2.

$$
\begin{aligned}
& R R=\frac{2 W}{\mathbb{l}} ; M R=\frac{d^{2}-\mathbb{1}^{2}}{d^{2}} x 100 ; \mathrm{CR}=\frac{w}{d} ; \\
& F P=\frac{L}{d} ; F R=\frac{\mathbb{I}}{d}
\end{aligned}
$$

Where, $\mathrm{RR}=$ Runkle Ratio, $\mathrm{MR}=$ Muhlsteph Ratio $(\%)$, $\mathrm{CR}=$ Coefficient of Rigidity, $\mathrm{FP}=$ Felting Power, $\mathrm{FR}=$ Flexibility Ratio, $l=$ diameter lumen, $\mathrm{L}=$ fiber length $(\mu \mathrm{m}), \mathrm{D}=$ fiber diameter $(\mu \mathrm{m}), \mathrm{w}=$ wall thickness $(\mu \mathrm{m})$.

\section{RESULTS AND DISCUSSION}

\section{Anatomical structure properties of royal palm leaf sheath}

The observations of the leaf sheath surface in this study were conducted on three different parts or sections i.e. the outside, middle and inside in the wide direction. Same with the morphological of palm in general (Khalil et al. 2006, Chen et al. 2017), in the transverse section of royal palm leaf sheath were composed of two main components i.e. primary vascular bundle and parenchymal tissue. SEM analysis found that in transverse cross-section the single vascular bundle was surrounded by parenchyma cells (Figure 2). The parenchyma cells will be decomposed and detached from vascular bundles after leaf sheath becoming 
mature and resulting completely separate from each other (Zhai et al. 2013). The shape of the vascular bundle of the royal palm leaf sheath was rounded to oval. The vascular bundles consisted of xylem (X), phloem $(\mathrm{Ph})$, and fiber bundles $(F)$. The dimension of xylem is bigger than the phloem. Zhai (2013) who studied the anatomical structure of several palms revealed the types of fibrovascular bundles. The types of fibrovascular bundles were most related to the phylogenetic classification of palm species.
The vascular bundles of royal palm (Roystonea regia) leaf sheath were categorized into type I as reported by Adzkia et al. (2020) who studied in the same palm species. Type I of fibrovascular bundles meant the vascular tissue rounded in the central region. This fiber bundle type was also the same with species of palm from other families Arecaceae such as Cocos nucifera (coconut), Elaeis guineensis (oil palm), and Phoenix dactylifera (date palm) (Zhai et al. 2013).

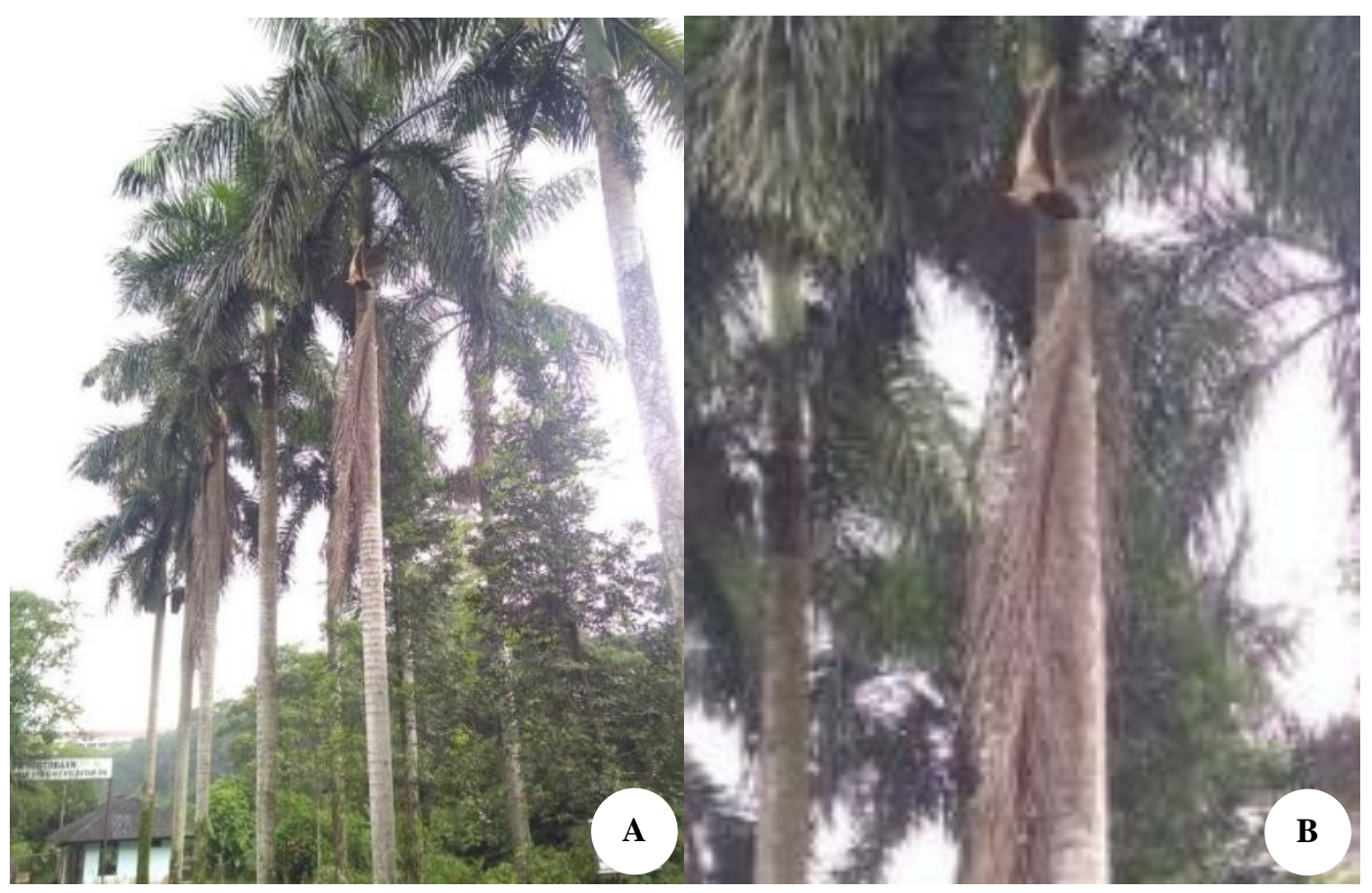

Figure 1. Royal palm plant tree. A. Habitus, B. Big size waste of royal palm leaves

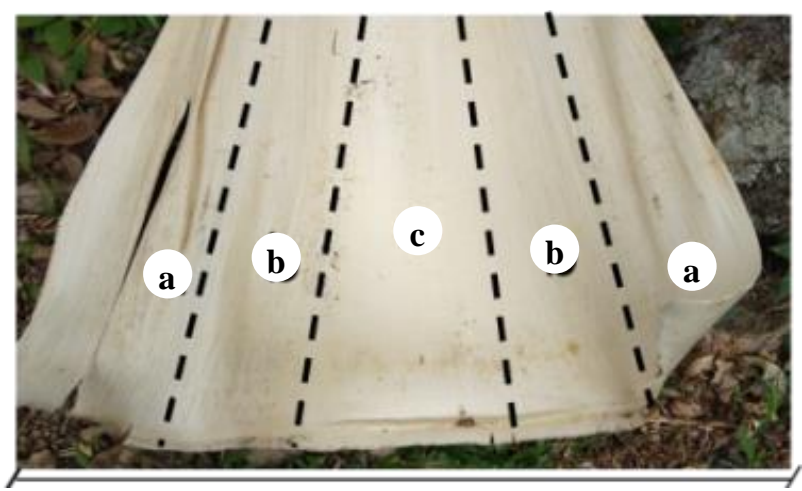

A

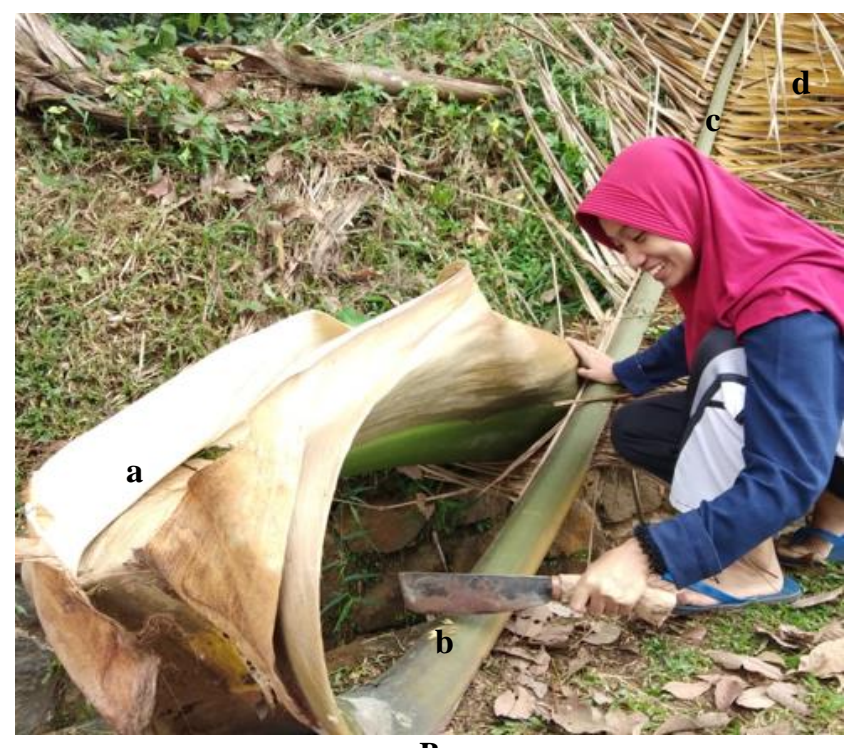

B

Figure 2. The leaf material of royal palm sheath. A. Width of leaf sheath: a. outside, b. middle, c. inside. B. Parts of leaves: a. Leaf sheath, b. Leaf stalk or petiole, c. Rachis, d. Leaflets 


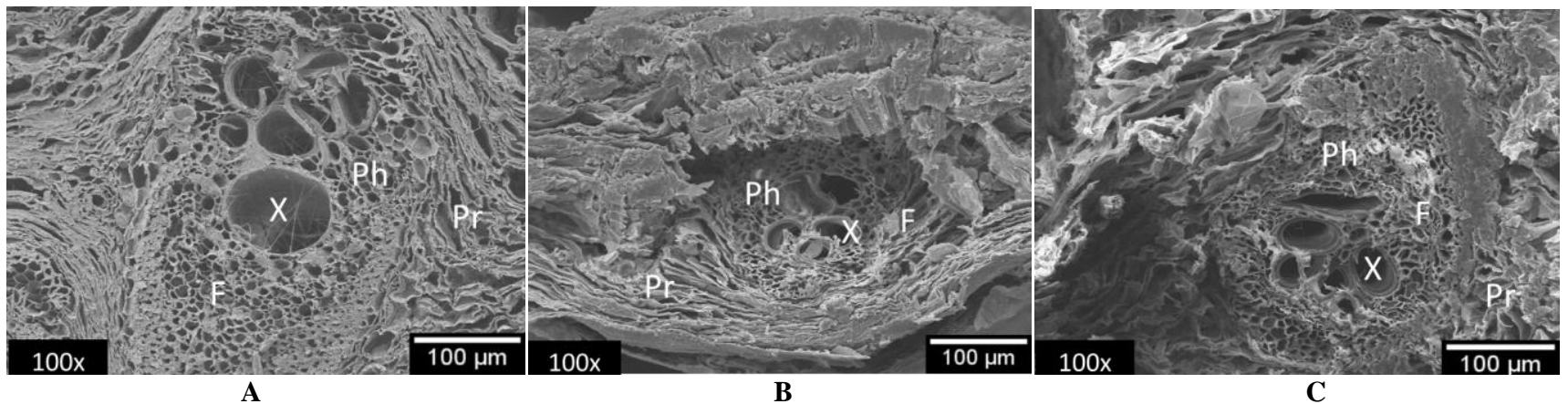

Figure 3. Transverse section of the royal palm leaf sheath at three sections in magnification 100X for (a) outside, (b) middle and (c) inside; dark-circle line is area of vascular bundles. $\mathrm{F}=$ Fibers, $\mathrm{X}=\mathrm{Xylem}, \mathrm{Ph}=\mathrm{Phloem}, \mathrm{Pr}=\mathrm{Parenchyma}$

Table 1. The elemental content in the royal palm leaf sheath for each section (outside, middle, and inside)

\begin{tabular}{|c|c|c|c|}
\hline \multirow{2}{*}{ Element } & \multicolumn{3}{|c|}{ wt (\%) } \\
\hline & Outside & Middle & Inside \\
\hline Oxygen $(\mathrm{O})$ & 47.68 & 42.47 & 44.98 \\
\hline Carbon (C) & 47.24 & 25.83 & 29.29 \\
\hline Calcium (Ca) & 2.34 & 18.51 & 12.84 \\
\hline Silicon $(\mathrm{Si})$ & 1.47 & 0.74 & 0.34 \\
\hline Sulfur (S) & 0.50 & 0.58 & 3.28 \\
\hline Sodium (Na) & 0.32 & 0.44 & - \\
\hline Magnesium (Mg) & 0.30 & 1.16 & 1.02 \\
\hline Aluminium (Al) & 0.14 & - & - \\
\hline \multicolumn{4}{|l|}{ Silica $\left(\mathrm{SiO}_{2}\right)$} \\
\hline Green & 7.67 & 8.28 & 9.92 \\
\hline Brownish-dry & 6.16 & 6.98 & 9.02 \\
\hline
\end{tabular}

Energy dispersive X-ray analysis (EDX) was used to determine the elemental content in the leaf sheath of the royal palm. The knowledge of essential element concentrations in leaves is useful for understanding ecological relations as well as improving managed plant protocols (Marler et al. 2019). Table 1 revealed that the highest element content detected was oxygen which found at all sections in palm leaf sheath for about $45 \mathrm{wt} \%$ followed by carbon, and calcium. The carbon element in the outside part was $47.24 \mathrm{wt} \%$ which higher than the middle of $25.83 \mathrm{wt} \%$ and inside part of $29.29 \mathrm{wt} \%$. Meanwhile $\mathrm{Ca}$ in the outside part was the lowest value was $2.34 \%$ compared with the middle and inside part which was $18.51 \%$ and $12.84 \%$, respectively. Silicon, sulfur, and magnesium elements were also found in palm leaf sheath with number varied between $0.30 \%$ to $4.28 \%$. Sodium element was not found in the inside section, while Al was not detected for both middle and inside sections.

Silicon is a major inorganic constituent that accumulates in a small number in plant cells (Epstein 1999). Silicon itself is an element that readily bonds with oxygen to become silicon dioxide or silica. Silica is accumulated as a consequence of water absorption from the soil and transpiration from the upper parts of the plant, namely, the epidermis. Silica could protect plants against herbivores and confers the leaves some structural support which can be an effective defense against pathogens, insects, and animals (Lins et al. 2002). From the study, it seemed that silica was not directly affected by the Si content but there was involved from other elemental content such as oxygen and carbon. Silica compounds in plants related to straightening the leaves (Tripathi et al. 2017) as well as in increasing plant growth (Artyszak 2018). However, the presence of silica compounds in a product could stipulate the reduction of calorific value (Demirbas 2007) and caused the abrasion of cutting tools (Darmawan et al. 2012). As a raw material, the silica compound is useful in many industries especially in the semiconductor industry (Silviana and Bayu 2018). The organic silica (bio-silica) of leaf sheath of royal palm in the green condition of outside, middle, and inside section were $7.6 \%, 8.28 \%$, and $9.92 \%$ by weight, respectively. Those values were higher than in brown-dry condition which the silica compound was $6.16 \%, 6.98 \%$, and $9.02 \%$ by weight for outside, middle, and inside section, respectively (Table 2). Others bio-silica such as from bamboo leaf contained $17-23 \%$ by weight, rice husk $(9.3-13.5 \%$ by weight) (Kow et al. 2014), oil palm empty-fruit bunch was 5.5\% (Law et al. 2007), and sago bark waste ( $1.3 \%$ by weight) (Siruru et al. 2019).

The average diameter of the vascular bundles in the inside section was $608.2( \pm 216.25) \mu \mathrm{m}$, in the middle of $550.7( \pm 61.36) \mu \mathrm{m}$, and in the outside of $480.4( \pm 84.53)$ $\mu \mathrm{m}$ as presented in Figure 3 and also reported by Adzkia et al. (2020). Bourmaud et al. (2017) released the classification of vascular bundle diameter which mentioning that a big size diameter of vascular bundles was greater than $600 \mu \mathrm{m}$, middle size in between 120 and 600 $\mu \mathrm{m}$, and small size was between $60-120 \mu \mathrm{m}$. The royal palm leaf sheath had the large diameter vascular bundles in the inside section followed by middle and outside sections. A Study by Quiroz et al. (2008) on the stem anatomical characteristics of the climbing palm (Desmoncus orthacanthos) from Arecaceae concluded that the diameter of vascular bundles was larger at the central inside and gradually decreased towards the outside section at peripheral zone. The vascular bundles diameter of the royal palm leaf sheath was smaller than the diameter of the vascular bundles of oil palm, which range from 800 to $1,000 \mu \mathrm{m}$ (Shirley 2002), and higher than vascular bundles 
diameter of windmill palm leaf sheath (Zhai 2013) and coconut palm leaf sheath (Satyanarayana et al. 1982). Furthermore, Quiroz et al. (2008) and Chen et al. (2017) mentioned that the dimension and number of unit of vascular bundle could be affected by the species as well as differences in the growth condition which may also be explained by differences among site variations in the microclimatic condition, even in the analogous palms. Moreover, the authors explained that the characteristics of vascular bundles can be contributed to the mechanical properties of the palm as raw materials.

\section{X-Ray Diffraction (XRD) and crystallinity characteristic}

XRD is a technique used to visualize the structure of a particular material. Information can be obtained from XRD as the crystallinity of the material. The composition of material will be read in the pattern formed by the material. The pattern formed might be in the form of a peak (Figure 4). The parameters of natural fiber such as the crystalstructure, the degree of crystallinity, the spiral angle of the fibrils, the degree of polymerization, the porosity content, the size of the lumen (a center void), and the chemical composition effected on the mechanical properties (Baley 2002, Bledzki and Gasan 1999). The comparison between crystallinity and amorph showed the level of crystallinity of the material (Mohammad 2007, Sawyer et al. 2008).

The degree of crystallinity indicates the number of crystals in a material by comparing the area of the crystal curve to the total area of the amorphous and crystals. The value of the degree crystallinity in the green and brownishdry leaf sheath of each section were shown in Table 2. The inside section possessed the highest degree of crystallinity, which was $17.775 \%$ and $18.070 \%$ for the green and brownish-leaf sheath of royal palm, respectively. The wave peaks that occur in each section formed the angular from $21.06^{\circ}$ to $22.42^{\circ}$ (Figure 5). This angle $2 \Theta$ corresponds to the $\mathrm{I}_{200}$ cellulose areas. Wada and Okana (2001) and Popescu et al. (2011) indicated that if the value of $2 \Theta$ was $14.5^{\circ}-15.3^{\circ}$ according to the plan (1-10), the value of $2 \Theta$ was $15.7^{\circ}-16.30^{\circ}$ depending on the areas (110), $2 \Theta$ was $18,3^{\circ}$ to $18,40^{\circ}$ in the amorphous field and $2 \Theta$ from $21,90^{\circ}$ to $22,20^{\circ}$ reflection assigned with a crystallographic plane of cellulose. The crystallographic plane is the name of the native cellulose structure. In Figure 6 at the $2 \theta$ for the first peak of $18,4^{\circ}$ indicated that the characteristics of the palm leaf sheath of royal palm were in an amorphous region. However, the amorphous region is unstable in the presence of water or moisture, and usually from partially crystalline cellulose II (Cialacu et al. 2011). From the result about the degree of crystallinity the outside section for both leaf sheath condition more permeable to water and chemical. Reddy and Yang (2005) mentioned about the lower crystallinity means a greater number of amorphous regions and more permeable to water and chemicals which meant high-water content. Cheng et al. (2014) stated that the higher moisture content in palm tree may be attributed to lower crystallinity as well as the rough morphology structure and abundant hollow sieve tubes.

The degree of crystallinity of the royal palm leaf sheath was different in the three sections according to the width (Table 2). The average degree of the crystallinity of the outside, middle, and inside green leaf sheath is $12.618 \%$, $12.397 \%$, and $17.775 \%$ respectively. This is different from the brownish leaf sheath which was outside, middle, and inside section possessed the values of $8.5743 \%, 12.269 \%$, and $18.070 \%$, respectively. The increasing value of the degree crystallinity in the inside might be caused by more organized this section than the middle and the outside sections. The value of the degree of crystallinity obtained by the royal palm leaf sheath was lower than that of other species such as sisal (Agave sisalana), pineapple (Ananas comosus) and banana (Musa paradisiaca), which were in a range of 30 to $60 \%$ (Bourmoud et al. 2017). The increase of the degree of crystallinity toward the inside section can be explained as in line with the result of silicon ( $\mathrm{Si}$ ) content from EDX analysis where the Si content inside was lower than in the middle and outside. Solikhin et al. (2016) and Santos et al. (2011) stated that increasing the crystallinity of material corresponds to the decline of the silicon content.

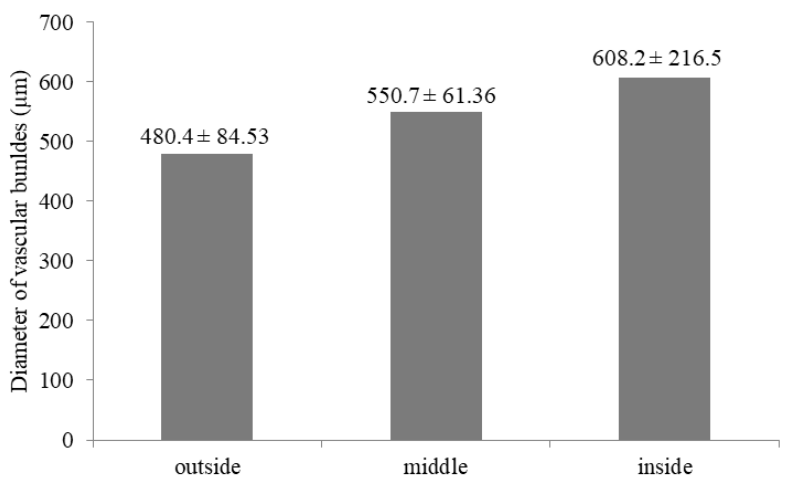

Figure 4. The vascular bundles diameter of royal palm in outside, middle, and inside at wide direction

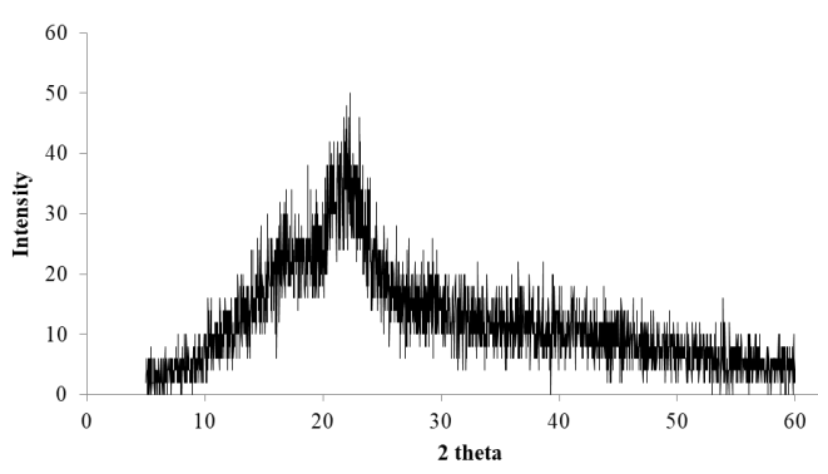

Figure 5. The graph about XRD pattern from materials 
Table 2. Degree of crystallinity the royal palm leaf sheath

\begin{tabular}{llll}
\hline $\begin{array}{c}\text { Condition of } \\
\text { the leaf } \\
\text { sheath }\end{array}$ & $\begin{array}{c}\text { Segmentation } \\
\text { of the leaf } \\
\text { sheath }\end{array}$ & $\begin{array}{c}\text { Degree of } \\
\text { crystallinity } \\
(\%)\end{array}$ & $\begin{array}{c}\mathbf{2 \theta}(\mathbf{2} \\
\text { theta) }\end{array}$ \\
\hline Green & $\begin{array}{l}\text { Outside } \\
\text { Middle }\end{array}$ & 12.618 & $22.42^{\circ}$ \\
& Inside & 12.397 & $20.56^{\circ}$ \\
& & 17.775 & $22.20^{\circ}$ \\
Brownish-dry & Outside & 8.5743 & $21.38^{\circ}$ \\
& Middle & 12.269 & $21.06^{\circ}$ \\
& Inside & 18.070 & $22.32^{\circ}$ \\
\hline
\end{tabular}

\section{Fiber characteristic}

The fiber characteristics of the royal palm leaf sheath in three section i.e. outside, middle, and inside were presented in Table 3. The diameter of the fiber, lumen, as well as wall thickness cells of green samples, was higher than brownish-dry samples. This is usually due to the brown leaf sheath older than the green leaf sheath. Cheng et al. (2014) mentioned about the diameter of fiber influenced by the age of the leaf sheath. The older the leaf sheath, the smaller the diameter fiber from the leaf sheath. Green vs brownish was pointed the maturity of the leaf sheath where the green was the newest of falling leaves. The average fiber diameter of the brownish-dry leaf sheath was in the range of $16-18 \mu \mathrm{m}$, while the green leaf sheath fiber diameter was in the range of 24-26 $\mu \mathrm{m}$. Meanwhile, the diameter lumen of the leaf sheath was in the range of $16-18 \mu \mathrm{m}$. The fiber diameter at interval $24-40 \mu \mathrm{m}$ was classified as "large" diameter, and the size of lumen diameter at that values was categorized in thin lumen Wagnefuehr (1984) in Kamaliah (2006).

The average length of the royal palm was $6388.35 \mu \mathrm{m}$ with the average fiber length of the brownish leaf sheath was higher than that of the green leaf sheath. Kamaliah (2016) explained in the oil palm leaf sheath that the older had the longer fiber length. Fiber derivation of royal palm leaf sheath consideration several aspects such as Runkle ratio, felting power, muhlsteph ratio, coefficient of rigidity, and flexibility ratio. The average Runkle ratio was more than 1 in the range of $1-2 \mu \mathrm{m}$. This value was the same with other palm leaf sheath which oil palm had Runkle ratio more than $2 \mu \mathrm{m}$. The high values of the Runkle ratio showed that the fiber had thick fiber walls and thin lumen, and for that reason, the fiber was difficult to flatten when milled. This type of fiber is thought to produce the paper with low tearing, cracking and tensile strength and lowquality pulp produced (Akpakpan et al. 2012; Syed et al. 2016).



Figure 6. X-ray diffractogram of royal palm leaf sheath for the sections outside, middle, and inside 
Table 3. Fiber characteristics in green and brown color of the leaf sheath

\begin{tabular}{|c|c|c|c|c|}
\hline \multirow{2}{*}{ Condition of the leaf sheath } & \multirow{2}{*}{ Derived fiber of leaf sheath } & \multicolumn{3}{|c|}{ Section of leaf sheath along the width } \\
\hline & & Outside & Middle & Inside \\
\hline \multirow[t]{9}{*}{ Green } & Diameter of fiber $(\mu \mathrm{m})$ & 24.24 & 26.70 & 24.19 \\
\hline & Diameter of lumen $(\mu \mathrm{m})$ & 12.37 & 13.51 & 12.84 \\
\hline & Wall thickness $(\mu \mathrm{m})$ & 5.82 & 6.59 & 5.68 \\
\hline & Fiber length $(\mu \mathrm{m})$ & 6278.43 & 7203.37 & 6542.25 \\
\hline & Runkle ratio & 1.28 & 1.42 & 1.23 \\
\hline & Felting power & 321.07 & 322.23 & 315.11 \\
\hline & Muhlsteph ratio (\%) & 76 & 76 & 73 \\
\hline & Coefficient of rigidity & 0.26 & 0.27 & 0.25 \\
\hline & Flexibility ratio & 0.47 & 0.46 & 0.5 \\
\hline \multirow[t]{9}{*}{ Brownish-dry } & The diameter of fiber $(\mu \mathrm{m})$ & 16.50 & 18.69 & 18.29 \\
\hline & The diameter of the lumen $(\mu \mathrm{m})$ & 7.75 & 8.16 & 9.04 \\
\hline & Wall thickness $(\mu \mathrm{m})$ & 4.38 & 5.27 & 4.63 \\
\hline & Fiber length $(\mu \mathrm{m})$ & 6498.28 & 6511.26 & 6512.36 \\
\hline & Runkle ratio & 1.31 & 1.51 & 1.23 \\
\hline & Felting power & 398.09 & 376.93 & 325.25 \\
\hline & Muhlsteph ratio (\%) & 78 & 80 & 76 \\
\hline & Coefficient of rigidity & 0.27 & 0.29 & 0.26 \\
\hline & Flexibility ratio & 0.46 & 0.43 & 0.48 \\
\hline
\end{tabular}

The felting power of royal palm leaf sheath was on an average of more than 300 . It means that the royal palm leaf sheath produced sheets with slippery surfaces in pulp raw material purposes. The value of the muhlsteph ratio, the coefficient of rigidity and the flexibility ratio of the royal palm were smaller than 0.8 , which was more than 0.15 , and was more than 0.15 , respectively. With those characteristics, the leaf sheath of royal palm was in the low-quality paper such as having a low tear, cracking, and tensile strength (Syed et al. 2016). Based on the observed fiber characteristics and fiber derivatives, the royal palm leaf sheath was not suitable for use as a raw material for pulp and paper, but it might be suitable when used as a reinforcement in composite products. This is because the royal palm leaf sheath possessed the fiber quite long was on average more than $6000 \mu \mathrm{m}$ so it meant the fiber in potential had high strength.

In conclusion, the morphological structure of royal palm sheath showed that the diameter of the vascular bundles royal palm leaf sheath was categorized large diameter with the inside section was the largest followed by middle and outside section. The elemental content detected was dominated by oxygen which found at all sections in palm leaf sheath followed by carbon, and calcium The element content of silicon ( $\mathrm{Si}$ ) in the inside section was lower than those in the middle and outside sections. It was in line with the degree of crystallinity in the inside section which that higher than other sections. The elemental content of Al was not found in both the middle and inside sections. The highest degree of crystallinity was about $18 \%$. The fiber length of royal palm leaf sheath was in values around $6000 \mu \mathrm{m}$. However, the royal palm leaf sheath had thick fiber walls and thin lumen, as well as other fiber derivation characteristics of muhlsteph ratio, the coefficient of rigidity and the flexibility ratio, were in lowquality values. For that reason, the royal palm leaf sheath was recommended to be developed as reinforce in composite products

\section{ACKNOWLEDGMENTS}

The authors would like to thank the Directorate for Research and Community Service, Ministry of Research Technology and Higher Education of the Republic of Indonesia (RISTEKDIKTI) (contract No 3/EI.KP.PTNBH/2019) for funding and supporting this research.

\section{REFERENCES}

Adzkia U, Nugroho N, Karlinasari L. 2020. Anatomical feature of the royal palm leaf sheath. Proceeding of International Seminar on Natural Resources and Environmental Management in Bogor. IOP Conf. Ser.: Earth Environ. Sci. 399 012061. IPB University, Bogor, 15 August 2019. DOI:10.1088/1755-1315/399/1/012061 [Indonesian]

Akpakpan AE, Akpabio UD, Obot IB. 2012. Evaluation of physicochemical properties and soda pulping of Nypa fruticans frond and petiole. Elixir Appl Chem 45: 7664-7668.

Anonymous. 2019. Kolesi Tanaman Palem Kebun Raya. KoleksiTanaman-Palem-Kebun-Raya-Bogor.html. http://krbogor.lipi.go.id/id/ [Indonesian]

Artyszak A. 2018. Effect of silicon fertilization on crop yield quantity and quality-a literature review in Europe. Plants 7 (54): 1-17. DOI: 10 3390/plants7030054.

Ayub B, Wani H, Shoukat S, Para PA, Ganguly S, Ali M. 2017. Specimen preparation for electron microscopy: an overview. J Environ Life Sci 2 (3): 85-88.

Baley C. 2002. Analysis of the flax fibers tensile behavior and analysis of the tensile stiffness increase. Composites: Part A 33: 939-948.

Bledzki AK, Gasan J. 1999. Composites reinforced with cellulose-based fibers. Prog Polym Sci 24: 221-274.

Bourmaud A, Dhakal H, Habrant A, Pavadoni J, Siniscalco D, Ramage MH, Beugrand J, Shah UD. 2017. Exploring the potential of waste 
leaf sheath date palm fibers for composite reinforcement through structural and mechanical analysis. Composite: Part A 103: 292-303.

Broschat TK. 2017. Roystonea regia: Royal Palm. University of Florida, Florida.

Bryan LSS, Daniella RM. 2012. Study of the potential use of royal palm fibers in the HDPE matrix. Proceeding $15^{\text {th }}$ European Conference of Composite Materials. Venice, Italy, 24-28 June 2012. [Italy]

Chauhan S, Bhushan RK. 2017. Study on polymer matrix composite with natural particulate/fiber in PMC: A Review. Int J Adv Res Ideas Innov Technol 3 (3): 1168-1179.

Chen C, Sun G, Chen G, Li X, Wang G. 2017. Microscopic structural features and properties of single fibers from different morphological parts of the windmill palm. BioResource 12 (2): 3504-3520.

Cheng L, Zhang T, Guo M, Li X. 2014. Structural characteristics and properties if windmill palm leaf sheath fiber. Wood Fiber Sci 46 (2): 270-279.

Cialacu D, Cialacu F, Popa VI. 2011. Amorphous cellulose-structure and characterization. Cellulose Chem Technol 45 (1-2): 13-21.

Darmawan W, Rahayu I, Nandika D, Marchal R. 2012. The importance of extractives and abrasives in wood materials on the wearing of cutting tools. Bioresources 7 (4): 4715-4729.

Demirbas A. 2007. Effects of moisture and hydrogen content on the heating value of fuels. Energy Sour 29: 649-655. DOI: 10.1080/009083190957801.

Dransfield J, Uhl NW, Asmussen CB, Baker WJ, Harley MM, Lewis CE. 2008. Genera Palmarun. The Evolution and Classification of Palms. Royal Botanic Gardens, Kew.

Epstein E. 1999. Silicon. Ann Rev Plant Physiol Plant Mol Biol. 50: 641664. https://doi.org/10.1146/annurev.arplant.50.1.641

Gumuskaya E, Usta M, Kirei H. 2003. The effects of various pulping conditions on the crystalline structure of cellulose in cotton litters. Polym Degrad Stability 81: 559-564.

Kamaliah. 2016. Macroscopic nature of variation and microscopic midrib palm. Daun J 3 (1): 63-71. [Indonesian]

Khalil AHPS, Bhat IUH, Jawaid M, Zaidon A, Hermawan D, Hadi YS 2012. Bamboo fiber-reinforced biocomposites: A review. Mater Des 42: 353-368.

Khalil HPSA, Alwani MS, Omar AKM. 2006. Chemical composition, anatomy, lignin distribution, and cell wall structure of Malaysian plant waste fibers. BioResources 1 (2): 220-232.

Kow KW, Yusoff R, Aziz AR A, Abdullah EC. 2014. From bamboo leaf to aerogel: Preparation of water glass as a precursor. J NonCrystalline Solids 386: 76-84. doi:10.1016/j.jnoncrysol.2013.11.041

Kumar KS, Siva I, Rajini N, Winowlin Jappes JT, Amico SC. 2016 Layering pattern effect on vibrational behavior of coconut/heath banana fiber hybrid composites. Mater Des 90: 795-803.

Law KN, Daud WRW, Ghazali A. 2007. Morphological and chemical nature of fiber strands of oil palm empty fruit bunch (OPEFB). BioResources 2: 351-362.

Lins U, Barros CE, Cunha MD, Miguens FC. 2002. Structure, morphology, and composition of silicon biocomposites in the palm tree Syagrus coronata (Mart.) Becc. Ptoroplasma 202: 89-96.

Marler TE, Krishnaphillai MV. 2019. Distribution of elements along the rachis of Cycas micronesia leaves: A cautionary note for sampling design. Horticulturae 5 (33): 1-8.
Mohammad F. 2007. Specialty Polymers. Materials and Applications. International Publishing House, New Delhi

Pei S, Chen S, Tong S. 1991. Angiospermae-Monocotyledoneae Palmae. Flora Rei Publicae Popularis Sinicae. Science Press, Beijing.

Pohan GA, Sugiarto T, Arianto DCG. 2018. Utilization of palm fiber royal palm as a strengthening material on biocomposite. J Sci Appl Eng 34: 2621-3745.

Popescu MC, Lisa G, Sakata Y. 2011. Evaluation of morphological and chemical aspects of different wood species by spectroscopy and thermal methods. J Mol Struct 988 (1-3): 65-72.

Quiroz J, Orellana R, Canto G, Rebollar S, Franci PH. 2008. Stem anatomical characteristics of the climbing palm Desmoncus orthacanthus (Arecaceae) under two natural growth conditions in a tropical forest. Rev Biol Trop Biol 56 (2): 937-949.

Reddy N, Yang Y. 2005. Biofibers from agricultural byproducts for industrial applications. Trends Biotechnol 23 (1): 22-27.

Santos NBC, Gomes RM, Colodette JL, Resende TM, Lino AG, Zanuncio AJV. 2011. Comparison of methods for eucalypt wood removal extractives. Proceeding of 5th International Colloquium on Eucalyptus Pulp in Porto Seguro, Bahia, Brazil. May 9-12 2011 [Brazil]

Satyanarayana KG, Pillai CKS, Sukumaran K, Pillai SGK. 1982. Structure-property studies of fibers from various parts of the coconut tree. J Mater Sci 17 (8): 2453-2462.

Sawyer LC, Grubb DT, Meyers GF. 2008. Microscopy and Microanalysis. Springer, New York.

Shirley Mb. 2002. Cellular Structure of Stems and Fronds of 14 and 25Year-Old Elaeis guineensis Jacq. [Thesis]. Putra Malaysia University, Serdang [Malaysia]

Silviana S, Bayu WJ. 2018. Silicon conversion from bamboo leaf silica by magnesiothermic reduction dro development of $\mathrm{Li}$-ion battery anode. Proceeding of The 24th Regional Symposium on Chemical Engineering in Semarang, Diponegoro University, Semarang, 15-16 November 2017. [Indonesian]

Siruru H, Syafii W, Wistara INY, Pari G. 2019. Characteristics of Metroxylon rumphii (pith and bark waste) from Seram Island, Maluku, Indonesia. Biodiversitas 20 (12): 3517-3526.

Solikhin A, Hadi YS, Massijaya MJ, Nikmatin S. 2016. Morphological and chemo- thermal changes of oven-heat treated oil palm empty fruit bunch fibers during dry disk milling. J Indian Acad Wood Sci 14 (1): 9-17.

Syed FNN, Zakaria MH, Bujang JS. 2016. Fiber characteristics and papermaking of seagrass using hand-beaten and blended pulp. BioResources 11 (2): 5358-5380.

Tripathi D, Dwivedi MM, Tripathi DK, Chauhan DK. 2017. Silicon bioavailability in exocarp of Cucumis sativus Linn. 3 Biotech 7 (6): 386. DOI 10.1007/s13205-017-0960-x.

Wada M, Okana T. 2001. Localization of Ia dan Ib phases in algal cellulose revealed by acid treatments. Cellulose 8: 183-188

Zhai S, Horikawa Y, Imai T, Sugiyama J. 2013. Anatomical and mechanical characteristics of leaf-sheath fibrovascular bundles in palms. IAWA J 34 (3): 285-300.

Zhai S. 2013. Anatomical and Mechanical Features of the Palm Fibrovascular Bundle. [Disertation]. Kyoto University, Kyoto. [Japan] 